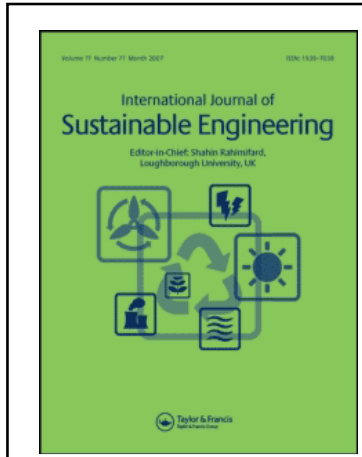

This paper is made available in accordance with Taylor \& Francis publisher policies. Please cite the original published version only using the following reference:

DOWSON M, HARRISON D, CRAIG S, GILL Z, 2011

Improving the thermal performance of single glazed windows using translucent granular aerogel, International Journal of Sustainable Engineering, volume 4, issue 3, pp 266-280

Link to official URL:

http://www.tandfonline.com/doi/abs/10.1080/19397038.2011.558931 


\title{
Improving the Thermal Performance of Single Glazed Windows using Translucent Granular Aerogel
}

\author{
Mark DOWSON ${ }^{1,2}$, David HARRISON ${ }^{1}$, Salmaan CRAIG ${ }^{2}$ and Zachary GILL ${ }^{2}$ \\ 1 - School of Engineering and Design, Brunel University, London, UB8 3PH, UK \\ 2 - Buro Happold Ltd, 17 Newman Street, London, W1T 1PD, UK
}

\begin{abstract}
Cost effective materials, products and installation methods are required to improve the energy efficiency of the UK's existing building stock. The aim of this paper is to assess the potential for high performance translucent granular aerogel insulation to be retrofitted over single glazing to reduce heat loss without blocking out all of the useful natural light. In-situ testing of a $10 \mathrm{~mm}$ thick prototype panel, consisting of a clear twin-wall polycarbonate sheet filled with granular aerogel was carried out and validated with steady state calculations. Results demonstrate that an $80 \%$ reduction in heat loss can be achieved without detrimental reductions in light transmission. Payback calculations accounting for the inevitable thermal bridging from openable solutions such as roller shutters or pop-in secondary glazing suggest that a return on investment between 3.5-9.5 years is possible if products are consistently used over the heating season. Granular aerogel is a promising material for improving the thermal performance of existing windows. Future research will seek to map out different ways in which the material can be applied to the existing UK housing stock, identifying which systems offer the greatest potential for widespread $\mathrm{CO}_{2}$ savings over their lifecycle.
\end{abstract}

\section{Keywords}

Granular aerogel; translucent insulation; retrofit products; energy efficient refurbishments

\section{Corresponding Author}

Mark Dowson, mark.dowson@burohappold.com

Mobile: (+44) 07706260523

Office: (+44) 02079279700 


\subsection{Introduction}

Reducing demand for heating and lighting in buildings is imperative for the UK to cut $80 \%$ of its $\mathrm{CO}_{2}$ emissions by 2050, in relation to the 1990 baseline (Climate Change Act 2008). In 2008 , the country's 26 million dwellings were responsible for $27 \%$ of all $\mathrm{UK} \mathrm{CO}_{2}$ emissions (Utley and Shorrock 2008). Non-domestic buildings were accountable for a further 20\% (RCEP 2007). It is anticipated that over $80 \%$ of the current building stock will still be in use by 2050 (Ravetz 2008, Power 2008). This is a major issue, since millions of these properties contain elements such as solid walls, single glazing and un-insulated floors responsible for a significant amount of wasted heat. These features are expensive and disruptive to improve, furthermore, associated improvements can be limited by available space and planning restrictions (Beaumont 2007, EEPH 2008).

This paper focuses on the potential to improve the performance of glazing in existing buildings. Windows typically lose 4-10 times more heat per $\mathrm{m}^{2}$, compared to walls, roofs and floors (Roberts 2008). According to Shorrock et al. (2005), new double glazing is not cost effective, with estimated payback periods lasting up to 98 years. In 2006, approximately 3 million dwellings in England contained full single glazing and 5.1 million homes contained 'some' single glazed windows (CLG 2006). Furthermore, approximately $70 \%$ of non-domestic buildings were constructed before double glazing became a legal requirement in 1976 (Roberts 2008). Of the remaining stock, around three quarters contain first generation double glazed windows installed over 20 years ago (Roberts 2008, Ravetz 2008). These units possess uninsulated frames, deteriorated air seals, narrow air gaps and a high U-value (heat loss coefficient) of 3-4 W/m $\mathrm{m}^{2} . \mathrm{K}$ that does not meet modern Building Regulations (Roberts 2008).

\subsection{Literature Review}

A number of innovative glazing technologies have been developed to satisfy the growing demand for energy efficient buildings (Roberts 2008). Super insulating windows with U-values below $1 \mathrm{~W} / \mathrm{m}^{2} . \mathrm{K}$ can be achieved in several ways. The current focus is to develop products that combine the lowest possible U-value, with a relatively high G-value (solar heat gain coefficient) and light transmission, to ensure that heat loss is minimised without blocking out the useful energy and daylight from the sun (MTP 2007). Innovations include low iron glass, selective coatings, insulated gas fillings, insulated frames, triple glazing, vacuum glazing, chromic glass and photovoltaic glazing. Finding a balance between cost and in-situ performance over the lifespan is essential, particularly for measures that rely on sustaining a vacuum.

According to Baker (2008), there is a lack of in-situ studies analysing the thermal performance of low cost alternatives to double glazing. In response, Baker (2008) used an environmental chamber to measure the U-values of seven different retrofit measures including curtains, blinds, secondary glazing and wooden shutters fitted to single glazing. The single glazing (U-value $=$ $5.4 \mathrm{~W} / \mathrm{m}^{2} . \mathrm{K}$ ), was then replaced with modern double glazing (U-value $\left.=1.9 \mathrm{~W} / \mathrm{m}^{2} . \mathrm{K}\right)$ for comparison. Baker (2008) found that all measures reduced heat loss, yet most measures blocked out all natural light. The greatest reduction in heat loss came from a custom made set of wooden shutters lined with $9 \mathrm{~mm}$ of Spacetherm ${ }^{\mathrm{TM}}$, an opaque insulating blanket embedded with super insulating 'silica aerogel' particles. This one-off prototype achieved a centre pane U-value of $1.6 \mathrm{~W} / \mathrm{m}^{2} . \mathrm{K}$, reducing $60 \%$ of the overall heat loss. Baker (2008) concluded that an $80 \%$ reduction (equivalent to triple glazing) would be possible by designing a purpose built product.

There is scope to develop new retrofit technologies using transparent insulation materials (TIMs). These materials perform a similar function to opaque insulation, yet they have the 
ability to transmit daylight and solar energy, reducing the need for artificial light and heating. TIMs transmit heat, mainly through conduction and radiation, as convection is usually suppressed (Kaushika and Sumathy 2003). The thermal and optical properties of a TIM depend on the material, its structure, thickness, quality and uniformity. Depending on the structure of a TIM, its arrangement can be classified as absorber perpendicular, absorber parallel, cavity or quasi-homogeneous. These four types are illustrated in Figure 1. TIMs typically consist of either glass or plastic arranged in a honeycomb, capillary or closed cell construction.

Alternatively, granular or monolithic silica aerogel can be used to achieve higher insulation values.

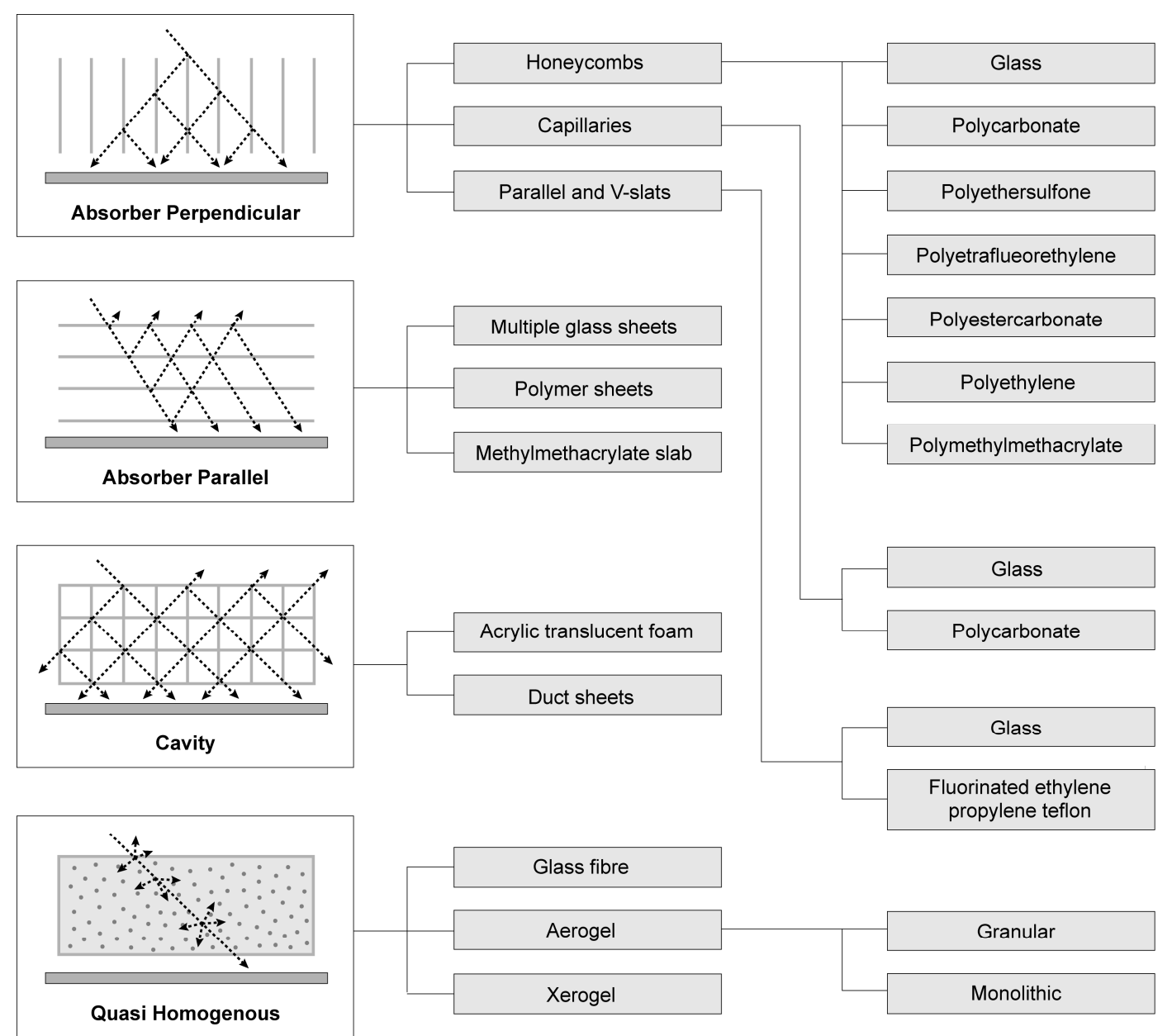

[Figure 1. Types of translucent insulation materials (Adapted from Wong et al. 2007)]

Honeycomb transparent insulation was first developed in the 1960s to enhance the insulation value of glazing systems with minimal loss to light transmission (Hollands 1965). Over the past 25 years, TIMs have been applied to windows, skylights, walls, roofs and high performance solar collectors (Dolley et al. 1994, Kaushika and Sumathy 2003). TIM glazing typically consists of glass or plastic capillaries or honeycomb structures sandwiched between two glass panes. These systems diffuse light well, whilst reducing glare and shadowing (Lein et al. 1997). Commercial products such as Okalux and Arel glazing can exhibit low U-values with good solar and light transmittance. According to Hutchins and Platzer (1996), 40mm thick Okalux capillary glazing, and 50mm thick Arel honeycomb glazing can achieve U-values of 1.36 $\mathrm{W} / \mathrm{m}^{2} . \mathrm{K}$ - comparable to modern gas filled double glazing. Alternatively, $80 \mathrm{~mm}$ and $100 \mathrm{~mm}$ thick systems can achieve U-values of $0.8 \mathrm{~W} / \mathrm{m}^{2} . \mathrm{K}$ respectively - comparable to modern gas filled triple glazing units. 
According to Robinson and Hutchins (1994), the application of TIM glazing tends to be limited to skylights, atriums and commercial / industrial facades as the geometric structure of TIMs tends to restrict a clear view outside. TIMs appear most transparent when viewed directly on, yet opaque when viewed at an angle. In order to increase visible transmission of TIM glazing it is important to increase capillary size, reduce the thickness or view the TIM from a distance (Lein et al. 1997). According to measurements by Hutchins and Platzer (1996), normal light transmittance through honeycomb and capillary TIM glazing is $78 \%$ and $84 \%$ respectively. By comparison, normal light transmission through standard double glazing was similar at $81 \%$. Low-emissivity gas-filled double and triple glazing units can be lower at $66 \%$ and $63 \%$ respectively (Hutchins and Platzer 1996).

Platzer and Goetzberger (2004), and Wong et al. (2007) claim that commercial uptake of TIMs has been slow, due to perceived high investment costs and small number of payback studies. Peuportier et al. (2000), states that production quality must improve to reduce imperfections such as rough or melted edges, which can hinder clarity. Comparatively, Kaushika and Sumathy (2003) state that considerable progress has been made to reduce the quality and cost of manufacturing transparent insulation. Although capital costs to manufacture a fully functional TIM cladding system with solar control can reach $€ 600-1000 / \mathrm{m}^{2}$, TIM glazing systems can have costs as low as $€ 24 / \mathrm{m}^{2}$ (Kaushika and Sumathy 2003, Wong et al. 2007). Based on this lower cost, Wong et al. (2007), calculated a 3-4 year payback period for an industrial production facility in Salzgitter Germany, renovated with $7500 \mathrm{~m}^{2}$ of TIM glazing costing $€ 180,000$ with annual maintenance costs of $€ 7200$. It is unclear whether these payback periods can be directly transferred to the domestic or commercial sector due to probably differences in design quality. Nonetheless, this payback period is significantly less than new double glazing.

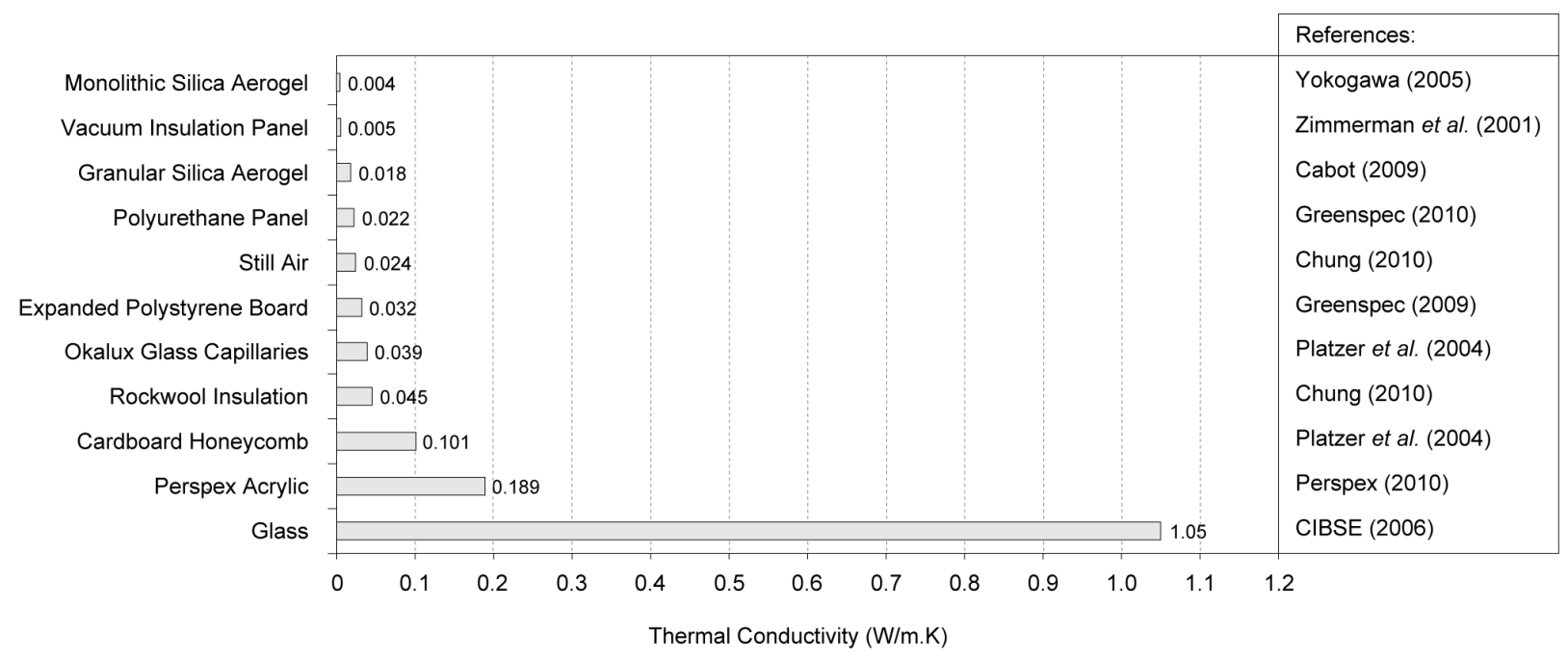

[Figure 2. Thermal conductivity of TIMs and insulation products]

State of the art research into TIM glazing focuses on developing systems using transparent silica aerogel. This lightweight, nanoporous material is the only known material with an excellent combination of high solar and light transmittance and low thermal conductance (Schultz et al. 2008). According to Bahaj et al. (2009) aerogel glazing is often portrayed as the 'holy grail' of future windows, offering potential to achieve U-values as low as $0.1 \mathrm{~W} / \mathrm{m}^{2} . \mathrm{K}$, as well as high solar energy and daylight transmittance of approximately 90\% (Bahaj et al. 2009, Schultz et al. 2008). The thermal, optical and infrared properties of silica aerogels are well known (Rubin and Lampert 1983, Platzer 1987, Fricke and Tillotson 1997, Yokogawa 2005). 
The material effectively transmits solar light whilst blocking heat transfer by conduction, convection and thermal infrared radiation (Fricke and Tillotson 1997). Silica aerogel has the lowest thermal conductivity of any material, ranging from $0.018 \mathrm{~W} / \mathrm{m} . \mathrm{K}$ for granular silica aerogel to $0.004 \mathrm{~W} / \mathrm{m} . \mathrm{K}$ for evacuated monolithic silica aerogel (Cabot 2009, Yokogawa 2005). Figure 2 displays the thermal conductivity of silica aerogel, compared to various TIMs and insulation products. As shown, only vacuum technology has a thermal conductivity of the same order of magnitude as aerogel (Zimmerman and Bertschinger, 2001).

To date, several small-scale prototypes have been constructed to characterise the performance of monolithic silica aerogel in glazing. Samples are sandwiched between glass sheets and evacuated to protect the aerogel from tension and moisture, as most aerogels are brittle and hydrophilic meaning they will degrade in contact with water (Schultz et al. 2008, Zhu et al. 2009). Duer and Svendsen (1998) measured the performance of five different monolithic aerogel slabs, produced at different laboratories, ranging in thickness from 7-12mm. Centre pane U-values of glazed samples ranged from $0.41-0.47 \mathrm{~W} / \mathrm{m}^{2} . \mathrm{K}$. Solar and visual transmittance ranged from $74-78 \%$ and $71-73 \%$ respectively. Jenson (2004), and Schultz et al. $(2005,2008)$, report on the performance of monolithic aerogel glazing produced by the Airglass AB plant in Sweden. The largest prototype was a $1.2 \mathrm{~m}^{2}$ window, consisting of four $55 \mathrm{~cm} \times 55 \mathrm{~cm} \times 15 \mathrm{~mm}$ monolithic tiles fitted into an evacuated, sealed framing unit. This prototype achieved a centre pane U-value of $0.66 \mathrm{~W} / \mathrm{m}^{2} . \mathrm{K}$ (measured in a lab), and an overall U-value of $0.72 \mathrm{~W} / \mathrm{m}^{2} . \mathrm{K}$ (measured using a hot box), indicating that the effect of thermal bridging at the edges was small. The direct solar transmittance was $75-76 \%$ and the normal transmittance in the visible spectrum was $85-90 \%$.

Despite its impressive combination of thermal and optical properties, monolithic silica aerogel is yet to penetrate the commercial glazing market. According to Rubin and Lampert (1983), the cost, long processing time of aerogel, difficulty manufacturing uniform samples and lack of adequate protection from tension and moisture are key barriers hindering progress. Duer and Svendsen (1998) and Bahaj et al. (2009), state that further work is required to improve clarity of samples if they are to replace conventional windows. A key issue is that the nanostructure of silica aerogel scatters transmitted light resulting in a hazy view. Schultz et al. (2008) claim that through improved heat treatment techniques, the Airglass AB plant is capable of producing aerogel tiles with parallel and smooth surfaces, resulting in undistorted views when shielded from direct solar radiation. However, when exposed to non-perpendicular solar radiation, visual distortion still occurs. According to Jenson et al. (2004) and Schultz et al. (2005, 2008) aerogel glazing is an excellent option for large areas of north facing facades, enabling a net energy gain during the heating season. Through developments in edge sealing techniques, units are anticipated to have a lifespan of 20-25 years without degradation (Schultz et al. 2008).

The use of granular aerogel in glazing offers an alternative solution to monolithic aerogel that is cheaper, more robust and easier to produce on a commercial scale. Systems should not be considered as a direct replacement for transparent windows, since the granules restrict the clear view outside. Instead, this material offers potential to achieve low U-values, enhanced light scattering and drastically reduced sound transmission in areas where an outside view is not essential (Wittwer 1992). The largest manufacturer of aerogel granules is Cabot Corporation who produces Nanogel ${ }^{\circledR} 1-5 \mathrm{~mm}$ translucent, hydrophobic silica aerogel granules, which are completely moisture and mildew resistant (Cabot 2004). Cabot's production facility in Frankfurt Germany can produce about 10,000 tonnes of Nanogel ${ }^{\circledR}$ per year (Werner and Brand 2010). Companies such as Kalwall, Pilkington and Okalux are now using Nanogel ${ }^{\circledR}$ across a wide range of applications (Cabot 2004). Commercial products include filled polycarbonate, 
glass or GRP (glass-reinforced polyester) glazing units, skylights and structural building panels.

The performance of granular aerogel glazing was originally investigated by Wittwer (1992). Uvalues from $1.1-1.3 \mathrm{~W} / \mathrm{m}^{2} . \mathrm{K}$ were measured for $20 \mathrm{~mm}$ thick glazing units filled with granules ranging from 1-9mm in diameter. Smaller granules perform better thermally, as less heat is conducted through air gaps between granules. Optically, the larger aerogel granules permitted more light and solar transmission. More recently, Reim et al. $(2002,2005)$ measured and modelled the performance of granular aerogels encapsulated inside a $10 \mathrm{~mm}$ twin-wall plastic sheet, sandwiched between two glass panes with an insulated gas filling. The twin-wall sheet was selected to prevent granules from settling over time, creating a thermal bridge along the top edge. U-values as low as $0.37-0.56 \mathrm{~W} / \mathrm{m}^{2} . \mathrm{K}$ were calculated for prototypes containing krypton/argon gas fillings. Without the glass cover panes, the solar and light transmission was $88 \%$ and $85 \%$ respectively. Using a thermal model in a German climate, Reim et al. (2002) calculated the energetic benefit of granular aerogel glazing to be comparable to triple glazing. Results demonstrated that granular aerogel glazing could reduce the risk of overheating on southern and east/west facades. On north facing facades, the energetic balance of aerogel glazing was significantly better than triple glazing due to improved heat retention.

\subsection{Research Contribution}

The literature review identified no research papers looking at the potential for TIM to be retrofitted over existing single glazed windows to reduce heat loss without blocking out all of the useful natural light. There is also a lack of in-situ studies and payback studies looking at the performance of TIM in use. This paper aims to address these issues, whilst pursuing the opportunity to develop novel retrofit solutions using granular aerogel. Illustrated in Figure 3, granular aerogel can easily be poured inside plastic or glass casings to develop a host of novel retrofit solutions such as sliding, hinged or roller shutters, airtight venetian blinds or pop-in secondary glazing. As granular aerogel does not permit a clear view outside, solutions that can be closed during the evenings/night, but drawn out of the way when required may increase the widespread applicability across the housing stock. Alternatively, in applications where the outside view is not essential e.g. non-domestic buildings, then secondary glazing systems containing granular aerogel may be more appropriate.
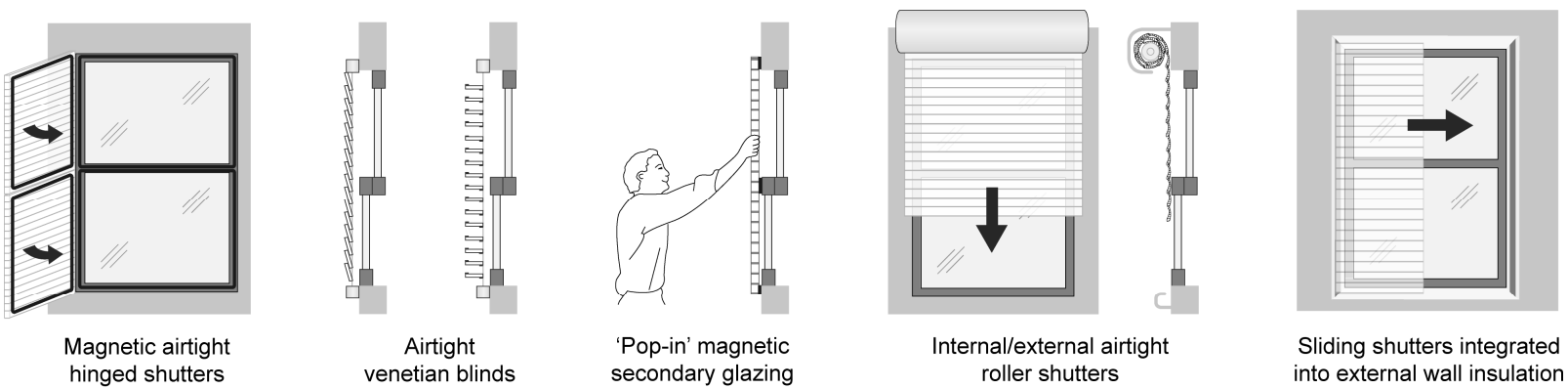

[Figure 3. Concepts to improve existing windows using encapsulated granular aerogel]

This paper aims to provide new in-situ measurements, validated with theoretical calculations to estimate the performance of these novel retrofit solutions in use. Specifically, this paper measures the resultant U-value and light transmission arising from retrofitting a translucent twin-wall polycarbonate panel filled with granular aerogel over an existing single glazed window. Two panel thicknesses are tested and compared, using an unmodified window as a control. The panels are permanently fixed over the entire window creating a reasonable airtight seal to represent the best operational scenario. Twin-wall polycarbonate is anticipated to be the most appropriate medium for encapsulating granular aerogel as the panel is lightweight, has a 
high impact resistance, and the twin-wall channels prevent the granules settling over time. Payback calculations based on the measured U-values are carried out to assess impact of the inevitable thermal bridging that would occur when openable solutions are introduced.

Note that solar transmission is not measured during the experiments and testing takes place in a north-facing window. According to Klems and Keller (1988), the effects of solar gain, can limit the accuracy of in-situ U-value measurements. If a south facing window was selected, then exposure to direct solar radiation could result in a net energy gain. Based upon commercially available data for polycarbonate sheets filled with aerogel granules (not retrofitted over existing glazing), solar transmission is anticipated to be $\pm 5 \%$ of the measured light transmission (Cabot 2010). The reason why in-situ testing was selected over laboratory testing was to gain a representation of the performance of the prototype under real conditions. Although laboratory testing allows extremely accurate measurements, it is difficult to account for the variation in wind, temperature and diffuse sky radiation, which can have a significant impact on a TIMs performance (Martin and Watson 1990).

\subsection{Method}

\subsection{Testing Environment}

In-situ testing took place during February-March 2010. Prototypes were set up in a highoccupancy office in Central London heated by conventional radiators. The candidate window was single glazed, north facing, well shaded, and had metal frames. The glazing was away from draughty doors and a radiator beneath the window was switched off. The glazing area contained eight panes of glass, each measuring $540 \mathrm{~mm} \times 680 \mathrm{~mm}$. Three adjacent panes were used during testing.

\subsection{Prototypes}

Figure 4 illustrates the arrangement of both prototypes and the control. The two prototypes consist of a twin-wall polycarbonate sheet manually filled with $3 \mathrm{~mm}$ diameter aerogel granules. One of these 'aerogel panels' was $6 \mathrm{~mm}$ thick, the other was $10 \mathrm{~mm}$ thick. Both prototypes were cut to fit neatly over the candidate window. They were sealed around the edges and securely attached to the internal face of the window frame using duct tape. A $15 \mathrm{~mm}$ air gap was created between the panels and the existing glazing. A measure of air tightness was not taken.

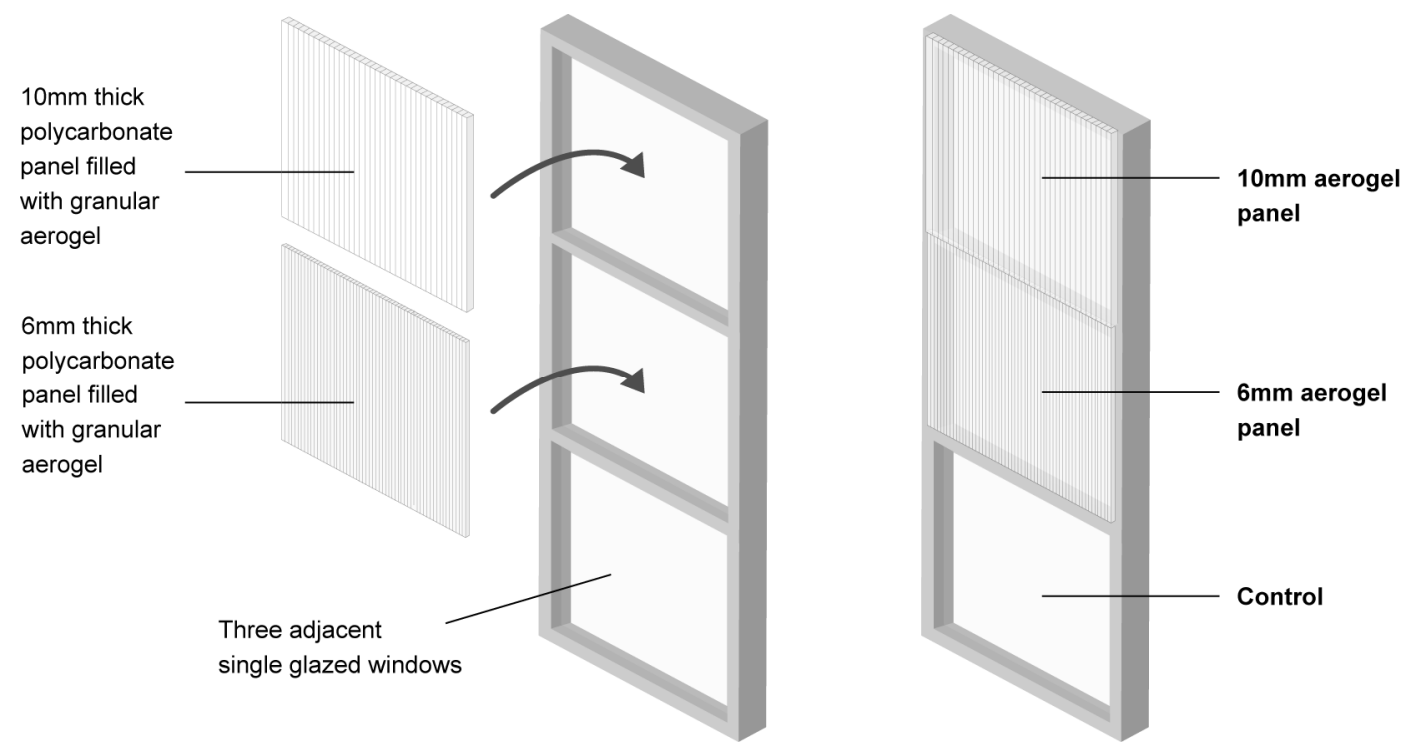

[Figure 4. Schematic diagram of the $6 \mathrm{~mm}$ aerogel panel, $10 \mathrm{~mm}$ aerogel panel and the control] 


\subsection{U-Value Measurements}

The layout of equipment used to measure the in-situ U-values of both prototypes and the control is shown on the left-hand diagram in Figure 5. Figure 6 displays photographs of the experiment once set up. Heat flux and temperature difference were monitored using three peltier modules and seven K-type thermocouples, connected to a CR23X micro logger - data sheet available from Campbell Scientific (2005). Heat flux, external, internal and surface temperatures were logged every 5 minutes.

Thermocouple measuring internal temperature

Peltier module measuring centre pane heat flux

Thermocouple measuring surface temperature

Thermocouple measuring

external temperature

Lux sensor measuring light transmission
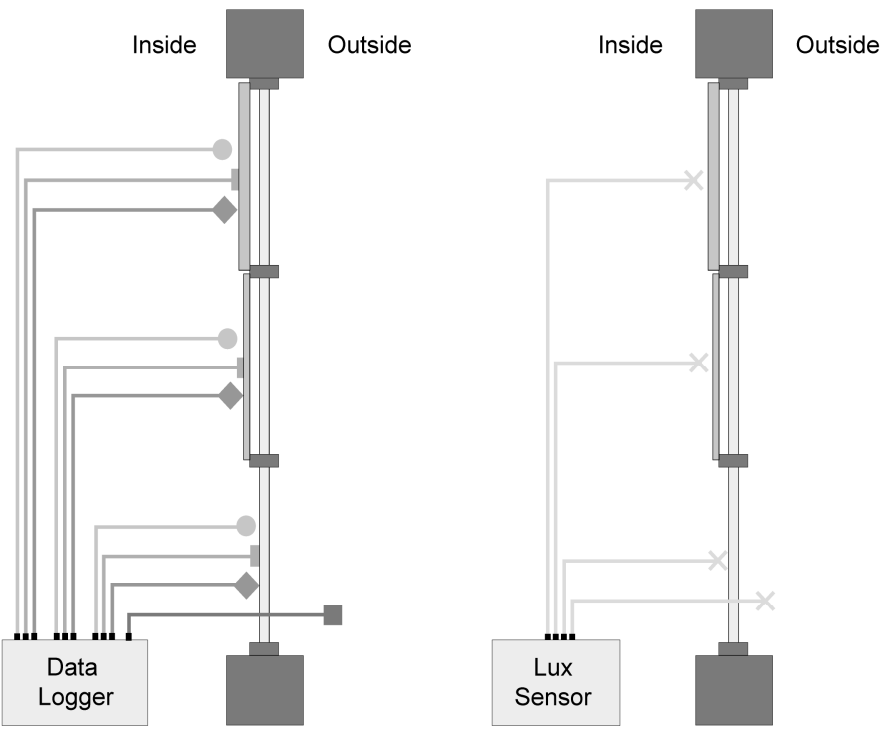

[Figure 5. Schematic diagrams of the thermal and optical monitoring equipment]

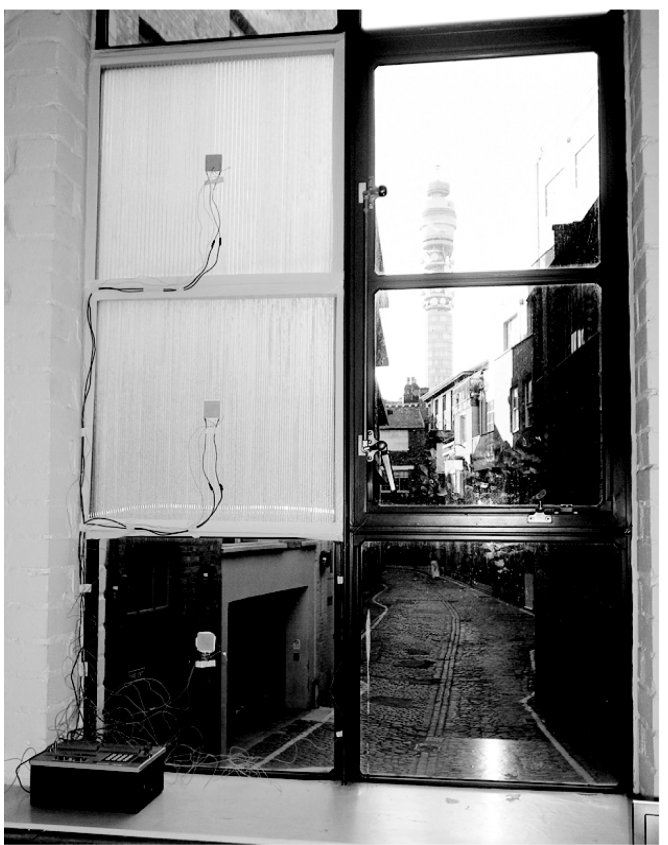

Left: Photograph showing the two aerogel panels and logging equipment mounted onto single glazing. The bottom left pane of glass was used as the control. The three panes on the right hand side were not used during testing. All glazing is north facing, contains metal frames and has no thermal breaks.

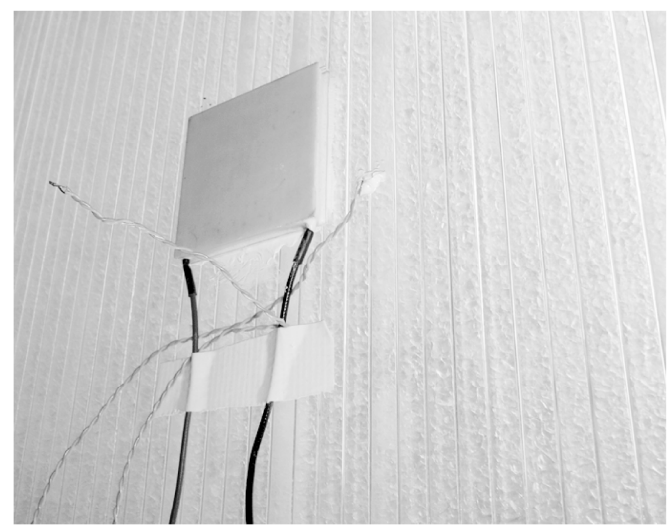

Above: Close-up photograph of the peltier module and two thermocouples mounted to the $10 \mathrm{~mm}$ thick aerogel panel.

[Figure 6. Photograph showing the prototype panels and monitoring equipment]

External temperature was monitored by positioning one thermocouple outside an adjacent, openable window, which was shut afterwards. Ambient internal temperature was monitored using three thermocouples pointing towards the indoor space, by the centre of both prototypes 
and the control. Three additional thermocouples were also used to monitor the internal surface temperatures for a robust monitoring process.

Heat flux was monitored using peltier modules thermally bonded to the centre of both prototypes and the control. A peltier module is a pre-assembled semi-conductor device, comprised of $\mathrm{P}$ and $\mathrm{N}$ type junctions, layered between two metal plates. Typically, these devices are used for their ability to become hot or cold when voltage passes through them. Reversing this function, the devices can generate a voltage when heat is induced across the plates. The voltage generated by this 'peltier effect' corresponds to a heat flux when multiplied by a calibration factor (Haruyama 2001).

\subsection{Measuring Light Transmission}

Light transmission was measured by positioning lux sensors at the points marked in the right hand diagram in Figure 5. Readings were taken in a range of outdoor conditions i.e. cloudy, sunny and during rain to represent different levels of day lighting. Internal readings were taken by holding the lux sensor approximately $5 \mathrm{~cm}$ away from the centre of each prototype panel and the control. Outdoor readings were taken by positioning the lux sensor outside of the adjacent operable window.

It is important that internal and external lux readings beside both prototype panels and the control be taken simultaneously as outdoor conditions can vary. For this experiment, only one sensor was available, therefore results will have an inherent degree of inconsistency relative to one another, due to minor delays (of a few seconds) between tests.

\subsection{Steady-State Calculations}

\section{$5.1 \quad$ U-Values}

The $\mathrm{U}$-value $\left(\mathrm{W} / \mathrm{m}^{2} / \mathrm{K}\right)$ of the prototypes is given by the following equation:

$\mathrm{U}=1 /\left(\mathrm{R}_{\text {external surface }}+\mathrm{R}_{\text {single glazing }}+\mathrm{R}_{\text {air gap }}+\mathrm{R}_{\text {aerogel panel }}+\mathrm{R}_{\text {internal surface }}\right)$

The total U-value for each system is calculated from the mean thermal resistance (R-value) of each layer, considering their upper and lower limits. The thermal resistances of the internal surface, external surface and the air gap were calculated in accordance with BS EN ISO 6946:2007. The air gap was treated as an unventilated air layer, with upper and lower limits accounting for the combined heat transfer coefficients for convective and long wave radiation. The centre pane thermal resistance of the single glazing was calculated by dividing the measured the thickness of the glass $(4 \mathrm{~mm})$ by an upper limit of $1.05 \mathrm{~W} / \mathrm{m}$.K (CIBSE 2006, pp174) and lower limit $0.96 \mathrm{~W} / \mathrm{m} . \mathrm{K}$ (Chung 2010, pp297) for its thermal conductivity.

Data on the thermal resistances for both aerogel panels were obtained from personal communication with R. Lowe (25 March 2010) from Xtralite - a company who supply polycarbonate panels filled with aerogel granules. The upper limits of the aerogel panels are based on the information provided, and the lower limits are based on a $15 \%$ reduction in performance, accounting for the manual filling process. This lower limit was selected based upon a measured test, which took place at Glasgow Caledonian University on 30/03/2010, comparing the thermal conductivities of a manually filled and industrial filled aerogel panel.

Table 1 displays the upper, lower and mean thermal resistances for each layer within the prototypes and control. An emissivity range of 0.89-0.95 was used when calculating the upper and lower range of internal surface resistances for the control (CIBSE 2006, pp183; Bynum 
2001, pp249), compared to a range of 0.8-0.9 for the prototype panels (Jones and Rudlin 2006, pp223; Mitchell 2000, pp24).

\begin{tabular}{|l|c|c|c|}
\cline { 2 - 4 } \multicolumn{1}{c|}{} & \multicolumn{3}{c|}{ R-value $\left(\mathrm{m}^{2} . \mathrm{K} / \mathrm{W}\right)$} \\
\hline Layer & Lower limit & Upper limit & Mean \\
\hline External surface & 0.0205 & 0.0621 & 0.0413 \\
\hline Single glazing & 0.0038 & 0.0042 & 0.0040 \\
\hline $15 \mathrm{~mm}$ air gap & 0.1790 & 0.2342 & 0.2066 \\
\hline 6mm aerogel panel & 0.2339 & 0.2752 & 0.2566 \\
\hline $10 \mathrm{~mm}$ aerogel panel & 0.4404 & 0.5181 & 0.4793 \\
\hline Internal surface (prototypes) & 0.1313 & 0.1811 & 0.1562 \\
\hline Internal surface (control) & 0.1211 & 0.1548 & 0.1380 \\
\hline
\end{tabular}

[Table 1. Upper, lower and mean thermal resistances for each layer within the prototype panels and control]

Table 2 displays the calculated U-values at the centre pane of both prototype and the control. According to calculations, the $6 \mathrm{~mm}$ aerogel panel yields a U-value of $1.54 \mathrm{~W} / \mathrm{m}^{2} . \mathrm{K}$ and the $10 \mathrm{~mm}$ aerogel panel yields a U-value of $1.15 \mathrm{~W} / \mathrm{m}^{2} . \mathrm{K}$. By comparison, the control has a much higher U-value at $5.70 \mathrm{~W} / \mathrm{m}^{2} . \mathrm{K}$.

\begin{tabular}{|l|c|c|c|}
\cline { 2 - 4 } \multicolumn{1}{c|}{} & \multicolumn{3}{c|}{ U-value $\left(\mathrm{W} / \mathrm{m}^{2} . \mathrm{K}\right)$} \\
\cline { 2 - 4 } \multicolumn{1}{c|}{} & Worst case & Best case & Mean \\
\hline Control & 6.88 & 4.52 & 5.70 \\
\hline $6 \mathrm{~mm}$ aerogel panel & 1.76 & 1.32 & 1.54 \\
\hline $10 \mathrm{~mm}$ aerogel panel & 1.29 & 1.00 & 1.15 \\
\hline
\end{tabular}

[Table 2. Calculated U-values for the prototype panels and the control]

\subsection{Heat Loss}

Figure 7 displays the estimated annual heat loss through a single glazed window retrofitted with both prototypes. Calculations were performed using hourly temperature data from the CIBSE TRY weather file for London (CIBSE 2008). The annual heating profile is assumed to operate at $21{ }^{\circ} \mathrm{C}$, all year round, with a night time set-back temperature of $18^{\circ} \mathrm{C}$ operating between $10 \mathrm{pm}-7 \mathrm{am}$. Four different product usage profiles are shown to represent how each aerogel panel might perform if adapted into an openable insulation solution, such as translucent airtight shutters or roller blinds etc. Profile 1 sets a baseline for the heat loss calculations; it assumes that the single glazing is un-insulated all year round and no benefit is gained.

Comparatively, Profiles 2-4 assumes the prototypes are consistently used from October 1st May 31 st, the months where approximately $90 \%$ of the degree-days for London Thames Valley occur (Vesma 2009). Profile 2 assumes the window is insulated from 10pm-7am. Profile 3 assumes the window insulated for longer from $6 \mathrm{pm}-8 \mathrm{am}$. Profile 4 assumes that the prototype is permanently insulating all day and night, thus behaving like secondary glazing.

According to calculations, both prototypes have large potential to improve the thermal performance of single glazing, cutting between $65-70 \%$ of the annual heat loss when permanently insulating over the heating season. Understandably, when considering openable insulation solutions, the degree of energy savings is highly dependent on how often the product is used. Preliminary calculations suggest that an openable solution can limit annual energy savings to $25-45 \%$. By using the product earlier in the evening and later in the morning, a higher proportion of heat losses can be reduced. Beyond product usage, note that the actual 
savings are also dependant on the internal baseline temperature. Furthermore, if a similar study was carried out in another region, or country, then the heating demand and subsequent heat loss could vary significantly.

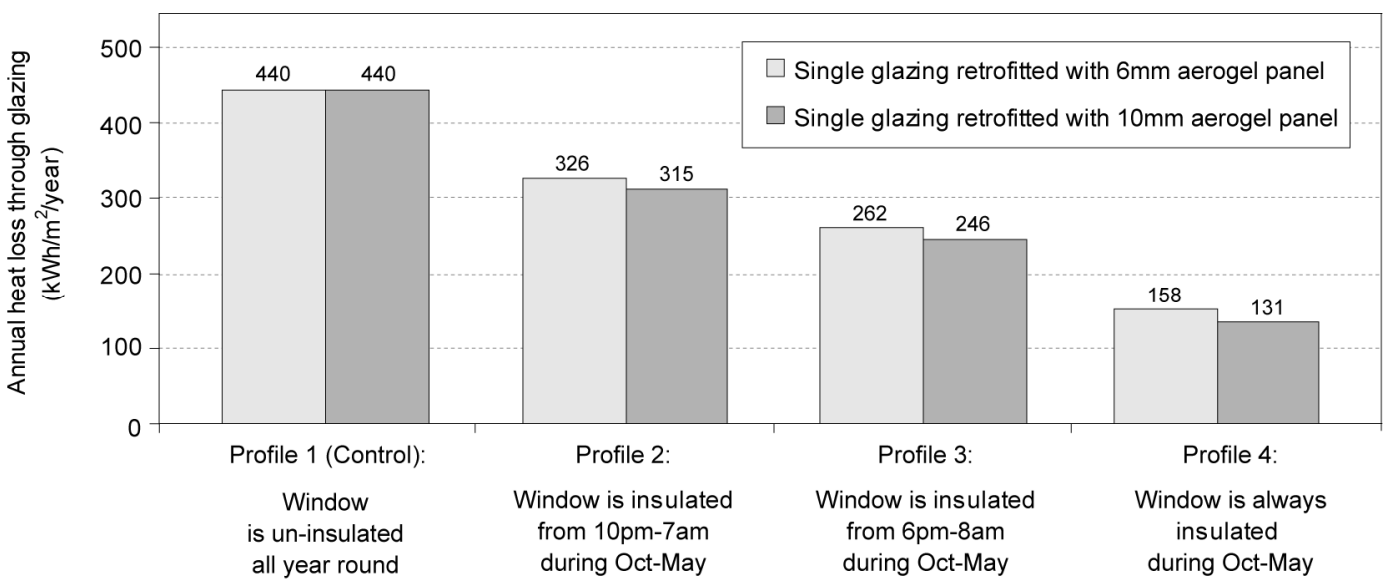

[Figure 7. Predicted annual heat losses through a single glazed window retrofitted with a $6 \mathrm{~mm}$ aerogel panel and $10 \mathrm{~mm}$ aerogel panel. Four operational scenarios are shown to illustrate the dependence of energy savings on product usage. Outside of the defined heating season, it is assumed that the window is un-insulated.]

\subsection{Light Transmission}

According to Cabot (2009) light transmission through aerogel decreases by $20 \%$ each time its thickness increases by $10 \mathrm{~mm}$. Figure 8 visualises this relationship. As shown, $6 \mathrm{~mm}$ of aerogel allows $88 \%$ of light transmission and $10 \mathrm{~mm}$ allows $80 \%$.

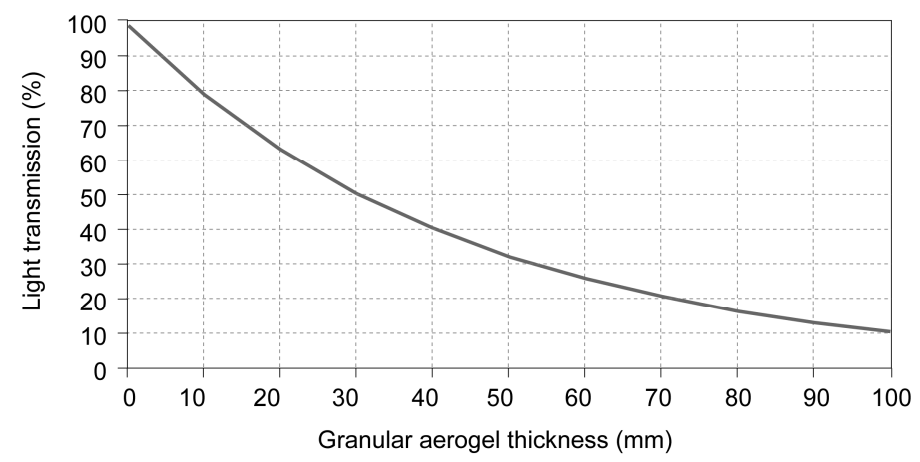

[Figure 8. Calculated light transmission through granular aerogel]

To calculate the light transmission of the entire system, the single glazing and the polycarbonate panels must also be considered. CIBSE (2006, pp 31) state that light transmission through single glazing, including the effects of dirt is $80 \%$. C\&A Supplies (2010) state that a $6 \mathrm{~mm}$ polycarbonate panels allows $85 \%$ light transmission and $10 \mathrm{~mm}$ panels allows $80 \%$. Multiplying the corresponding values together, the theoretical total light transmission through the $6 \mathrm{~mm}$ aerogel panel and $10 \mathrm{~mm}$ aerogel panel is $60 \%$ and $51 \%$ respectively.

\subsection{Results}

\subsection{Temperature Profile}

Figure 9 shows the external temperature and three ambient internal temperatures logged from $20 / 02 / 2010$ to $01 / 03 / 2010$. Over the 10 days, the average external temperature was $7.4^{\circ} \mathrm{C}$ with a 
maximum of $12.5^{\circ} \mathrm{C}$ and minimum of $2.1^{\circ} \mathrm{C}$. The average internal temperatures beside the control, $6 \mathrm{~mm}$ aerogel panel, $10 \mathrm{~mm}$ aerogel were $19.3^{\circ} \mathrm{C}, 20.0^{\circ} \mathrm{C}$ and $20.1^{\circ} \mathrm{C}$ respectively. The average surface temperature beside the control was $14.3^{\circ} \mathrm{C}$, whereas the $6 \mathrm{~mm}$ and $10 \mathrm{~mm}$ aerogel panels were several degrees warmer at $17.6^{\circ} \mathrm{C}$ and $18.3^{\circ} \mathrm{C}$ respectively.

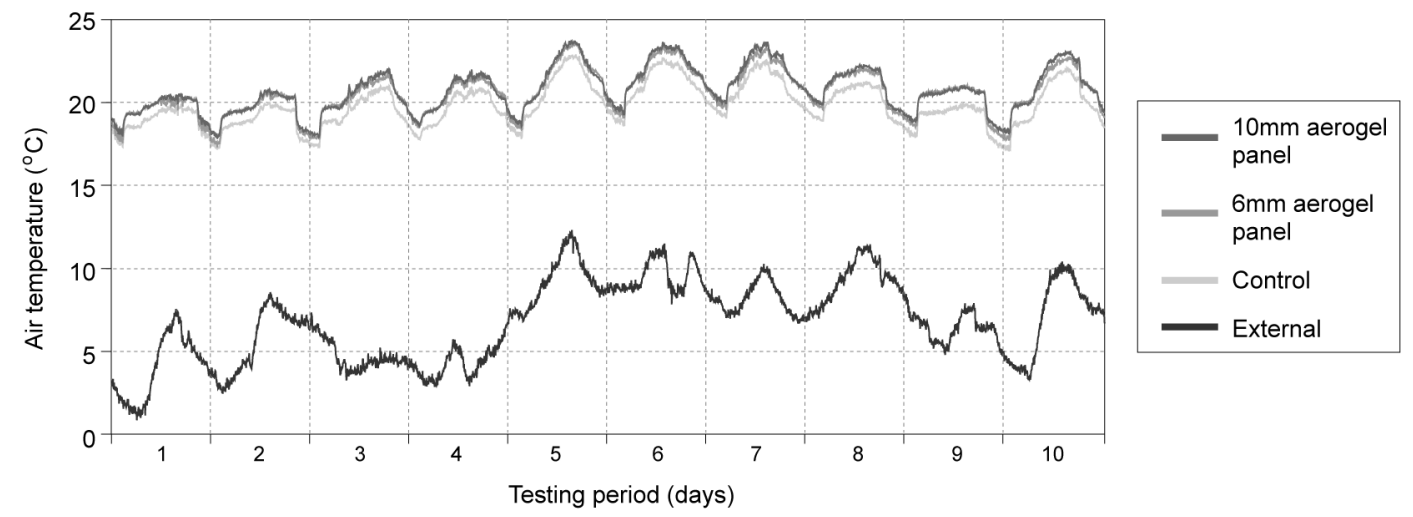

[Figure 9. Measured external temperature and three internal air temperatures besides the $6 \mathrm{~mm}$ aerogel panel, $10 \mathrm{~mm}$ aerogel panel and control during in-situ testing. Of the three internal readings, the $10 \mathrm{~mm}$ aerogel panel was consistently the warmest, closely followed by the $6 \mathrm{~mm}$ aerogel panel, then the control.]

\subsection{Heat Flux}

Figure 10 shows the induced heat flux from the peltier modules. Preliminary calibration of these units occurred on 14/12/2009 at Glasgow Caledonian University. Initial testing has shown the accuracy to be within $1 \%$ across a heat flux range of $0-20^{\circ} \mathrm{C}$. As expected, heat flux through the control was significantly larger than the heat flux through both prototypes. Studying the relative performance compared to the control, the $6 \mathrm{~mm}$ aerogel panel reduced heat flux by approximately $73 \%$ and the $10 \mathrm{~mm}$ aerogel panel by approximately $80 \%$.

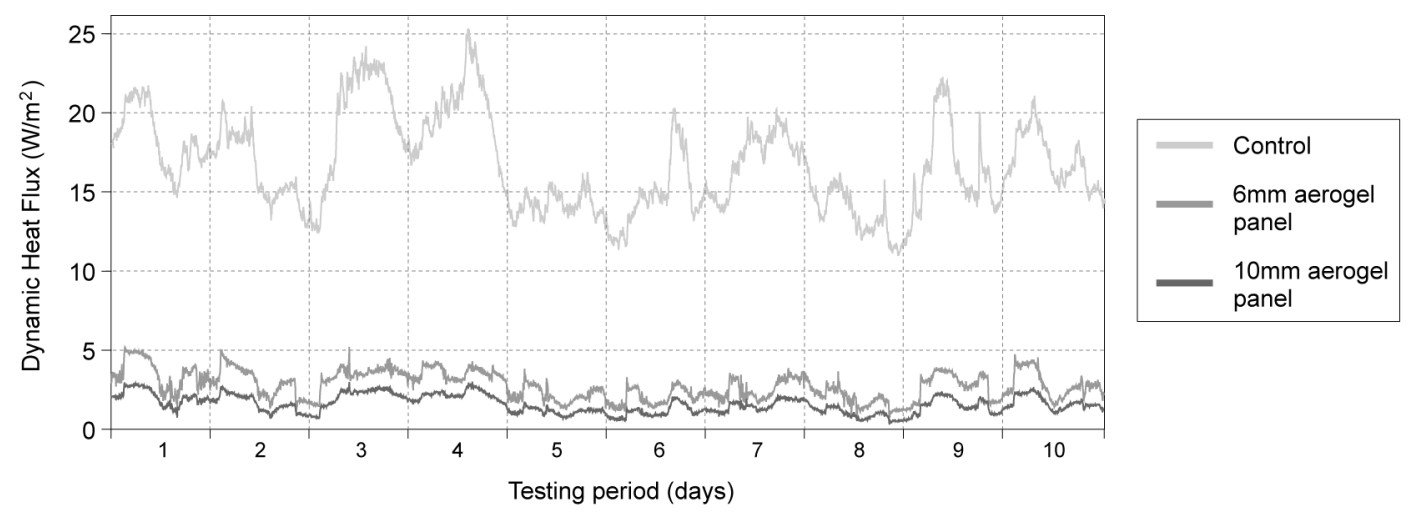

[Figure 10. Measured centre pane heat flux through the $6 \mathrm{~mm}$ aerogel panel, $10 \mathrm{~mm}$ aerogel panel and control during in-situ testing. Heat flux through the control was significantly large compared to the prototypes. Heat flux through the $10 \mathrm{~mm}$ aerogel panel was consistently the lowest of the three readings.]

\subsection{U-Values}

According to Cheeseman et al. (2007), instantaneous calculation of a U-value based on heat flux and temperature difference does not provide an accurate measurement of thermal transmission, due to the effects of time lag. This is especially true for higher insulating materials. Cheeseman et al. (2007) states that a dynamic in-situ U-value can be rationalised by calculating the cumulative average of the results over time. By applying the cumulative 
formula, the dynamic U-values of both prototypes appear to approach steady state between 3-5 days of testing. The control took approximately 7 days. According to the results, the control has a U-value of $6.39 \mathrm{~W} / \mathrm{m}^{2} . \mathrm{K}$, the $6 \mathrm{~mm}$ aerogel panel yields a $\mathrm{U}$-value of $1.54 \mathrm{~W} / \mathrm{m}^{2} . \mathrm{K}$ and the $10 \mathrm{~mm}$ aerogel panel yields a U-value of $1.17 \mathrm{~W} / \mathrm{m}^{2} . \mathrm{K}$.

\subsection{Light Transmission}

Figure 11 displays the measured light intensities at five time intervals throughout March 2010. Readings were taken during various external conditions. In all cases, results show that the control allows more light transmission, compared to both prototypes. The $10 \mathrm{~mm}$ aerogel panel reduced slightly more light transmission than the $6 \mathrm{~mm}$ aerogel panel.

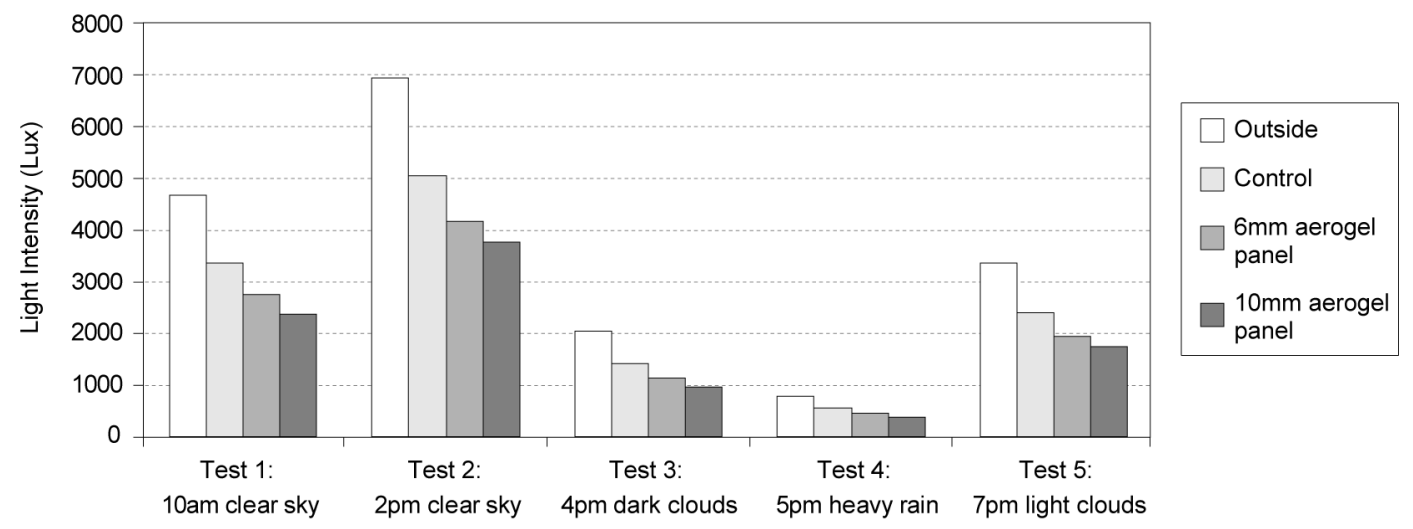

[Figure 11. Measured light intensity outside, compared to internal readings besides the control, $6 \mathrm{~mm}$ aerogel panel and $10 \mathrm{~mm}$ aerogel panel during five time intervals / weather conditions. Internal light transmission was consistently highest by the control, followed by $6 \mathrm{~mm}$ then $10 \mathrm{~mm}$ aerogel panels respectively.]

Figure 12 aggregates the lux readings as a percentage. As expected, the percentage of allowable light transmission across each test was not identical. Inconsistencies may be caused by delays when using the lux meter, dirt on windows, ridges in the polycarbonate panels, or variations in the aerogel granules. The average light transmission through the $6 \mathrm{~mm}$ aerogel panel, $10 \mathrm{~mm}$ aerogel panel and the control was $58 \%, 51 \%$ and $73 \%$ respectively.

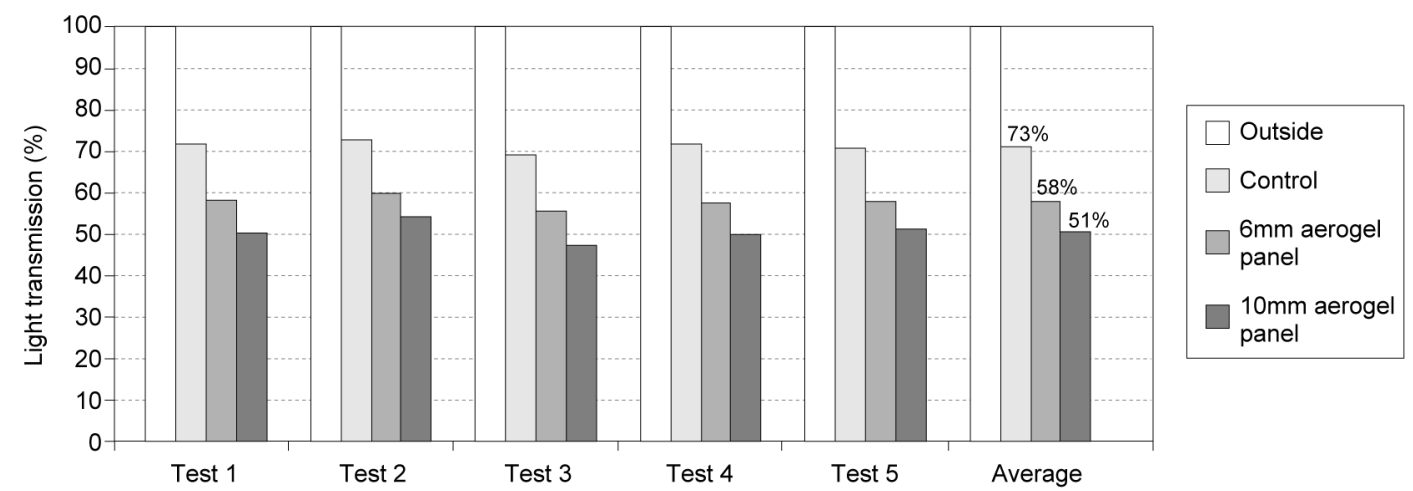

[Figure 12. Measured light transmissions from the five test periods aggregated as a percentage. Results show that the proportion of light transmission through the control and two prototypes compared to the outside was in close correlation across each test. The average percentage of light transmission is shown to the right.] 


\subsection{Discussion}

A summary of results from in-situ testing is shown in Table 3. The aim of this study was to assess the use of granular aerogel in a novel application and in a real time environment.

Experimentation has demonstrated the impressive thermal performance of this material. Based upon in-situ heat flux measurements, a $10 \mathrm{~mm}$ aerogel panel has been shown to prevent up to $80 \%$ of heat loss without detrimental impacts on light transmission. As shown in Figure 13, the measured U-values were within the allowable limits of the steady state calculations, indicating that both sets of results are in close agreement.

\begin{tabular}{|l|c|c|c|c|}
\cline { 2 - 5 } \multicolumn{1}{c|}{} & \multicolumn{2}{c|}{ Thermal performance } & \multicolumn{2}{c|}{ Optical performance } \\
\cline { 2 - 5 } & $\begin{array}{c}\text { Measured } \\
\text { U-value }\end{array}$ & $\begin{array}{c}\text { Reduction } \\
\text { in heat loss }\end{array}$ & $\begin{array}{c}\text { Measured } \\
\text { transmission }\end{array}$ & $\begin{array}{c}\text { Reduction } \\
\text { in light }\end{array}$ \\
\hline Control & $6.39 \mathrm{~W} / \mathrm{m}^{2} \cdot \mathrm{K}$ & - & $73 \%$ & - \\
\hline $6 \mathrm{~mm}$ aerogel panel & $1.54 \mathrm{~W} / \mathrm{m}^{2} . \mathrm{K}$ & $74 \%$ & $58 \%$ & $22 \%$ \\
\hline $10 \mathrm{~mm}$ aerogel panel & $1.17 \mathrm{~W} / \mathrm{m}^{2} . \mathrm{K}$ & $80 \%$ & $51 \%$ & $31 \%$ \\
\hline
\end{tabular}

[Table 3. Summary of in-situ testing results]

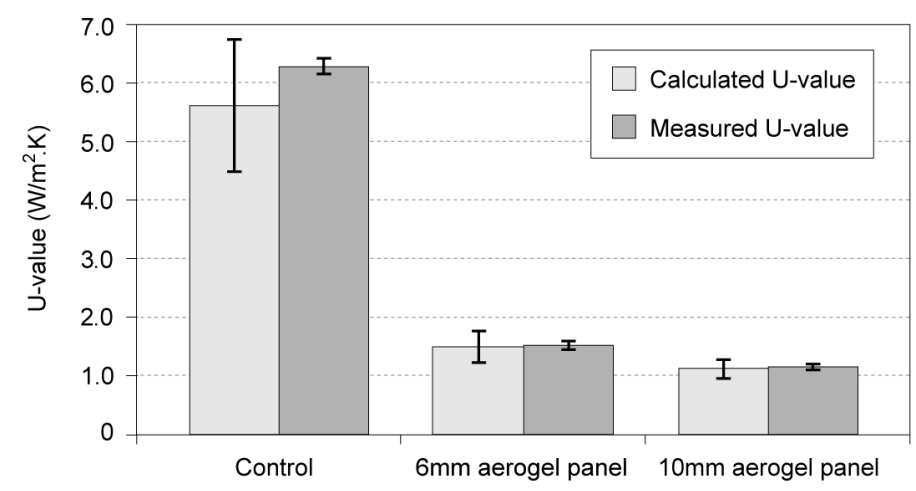

[Figure 13. Comparing the calculated and measured U-values]

Figure 14 displays a theoretical payback model for the $10 \mathrm{~mm}$ aerogel panel retrofitted to a single glazed window in a gas heated home. The model utilises a net present value equation with a discounted interest rate of 3.5\% (HM Treasury, 2009). Annual energy savings from heating were calculated using a baseline temperature of $21^{\circ} \mathrm{C}$ with an $18^{\circ} \mathrm{C}$ night time set-back between 10pm-7am. In-situ U-values were applied to the operational profiles described in Section 5.2, to account for openable insulation solutions. A unit cost of $£ 0.04 / \mathrm{kWh}$ was used to represent the cost of gas. A conventional gas-condensing boiler with a winter efficiency of $84 \%$ was selected to represent the heating system within a typical UK home (GGF 2009, SAP 2009, pp137). $£ 55 / \mathrm{m}^{2}$ was taken as the initial capital cost of the retrofit measure. This cost consisted of a $10 \mathrm{~mm} \times 1 \mathrm{~m}^{2}$ twin-wall polycarbonate priced $£ 10$ (C\&A Supplies 2010), eight litres of granular aerogel costing approximately $€ 4 /$ litre and a 50\% mark-up to cover additional costs such as airtight fixtures and installation. The cost of granular aerogel was obtained from personal communication with E. Ruiz (20 March 2009) of Cabot Corporation.

According to the payback calculations, the $10 \mathrm{~mm}$ aerogel panel could payback between 3.5-9.5 years, providing a positive return on investment of $£ 42-185 / \mathrm{m}^{2}$ over a 20 year product lifespan. These results are promising, especially when considering that new double and triple glazing does not provide a payback to a homeowner. Note that the 9.5 year payback calculation assumes that the window is only insulated between $10 \mathrm{pm}-7 \mathrm{am}$, when the heating profile is setback to $18^{\circ} \mathrm{C}$. A 5.8 year payback is calculated if the window is insulated for longer from $6 \mathrm{pm}-$ 
8am. Shorter paybacks could be expected if the capital cost of the product was driven down by the economies of scale associated with mass production. Furthermore, as this model does not account for potential increases in energy prices, this could reduce payback periods further. It is important to realise, however, that the true payback period is highly dependant on actual temperatures both inside and out, as well as how consistently the product is used over the heating season. If developed into an openable insulation solution, which is not used consistently, this could limit the cost effectiveness significantly.

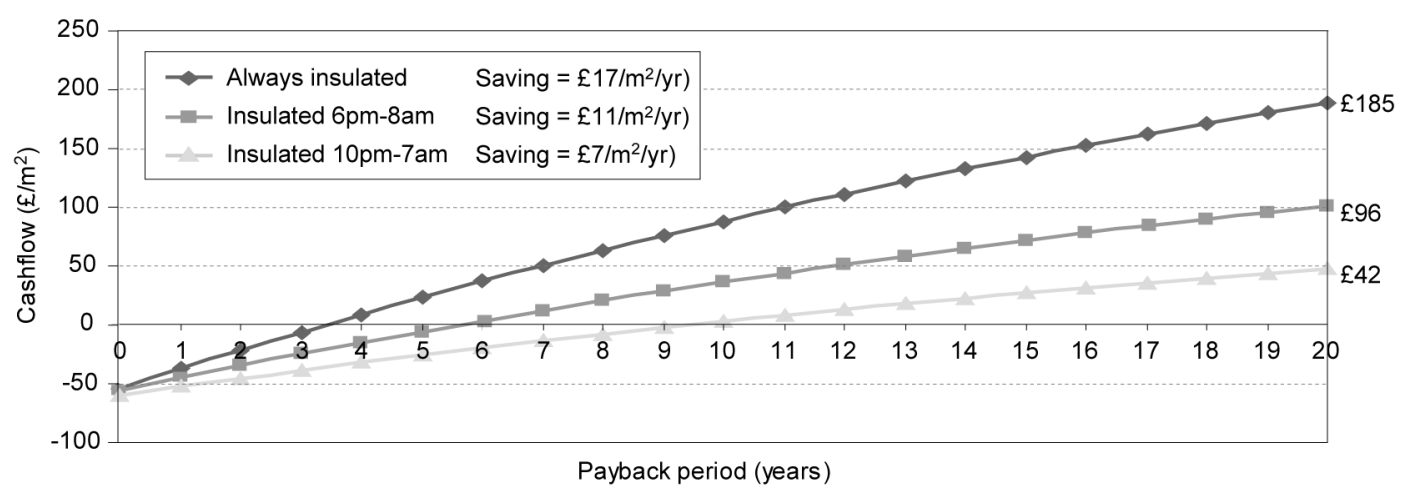

[Figure 14. Payback calculations for $10 \mathrm{~mm}$ aerogel panel retrofitted to single glazing]

Building Regulations Part L1B states that new glazed elements must achieve a centre pane Uvalue of $1.2 \mathrm{~W} \cdot \mathrm{m}^{2} . \mathrm{K}$ in order to meet refurbishment standards (HM Government 2010, pp19). According to this study, the $10 \mathrm{~mm}$ aerogel panel was capable of achieving this target without evacuating the panel or inserting a noble gas filling, demonstrating that granular aerogel can be used to achieve modern building standards at minimal costs. Future development should seek to maintain this performance, whilst developing suitable forms and airtight attachment methods tailored towards the needs of different occupants and buildings types. For openable solutions, efforts should be made to educate users on how to operate products effectively or develop products with control systems, such as automatic roller or sliding shutters to ensure maximum benefit can be gained.

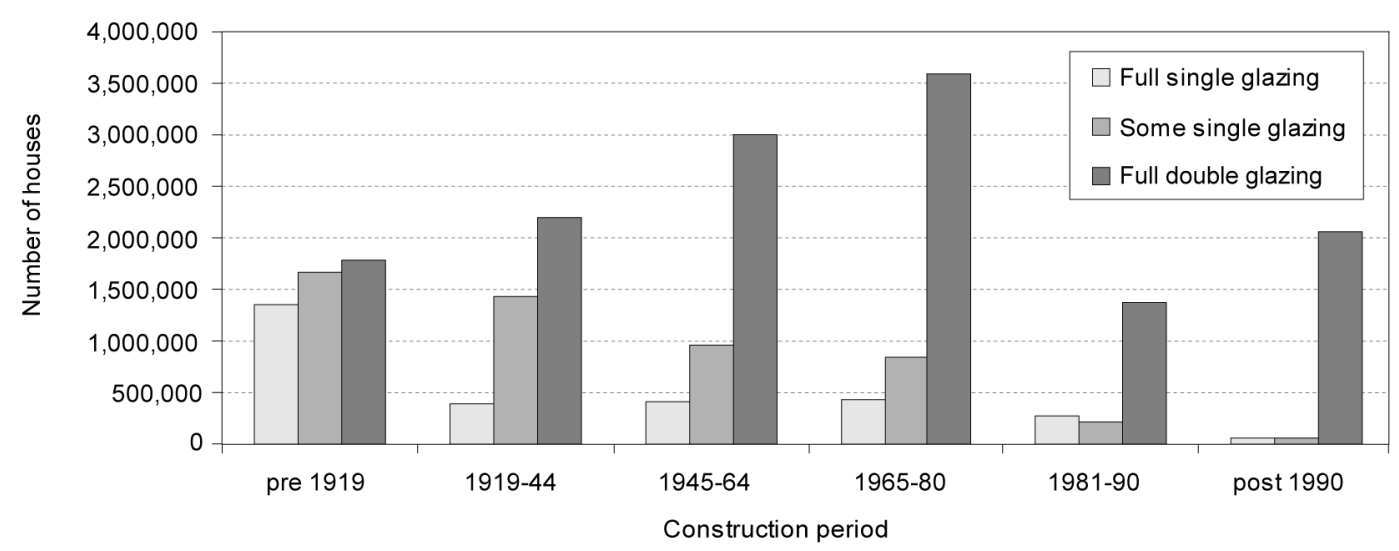

[Figure 15. The distribution of glazing types across the English housing stock by construction period (Generated from CLG 2006)]

Figure 15 shows the distribution of glazing types across the English housing stock by construction period. As seen, pre-1919 homes have the largest distribution of full single glazing. Additionally, a significant amount of homes constructed before the 1980s still have 'some' single glazed windows. According to the English Housing Survey (CLG 2010), private rented homes, dwellings in London and the South East and in village/city centres or isolated 
rural areas are the most likely properties to contain single glazing. It is envisaged that openable translucent insulation solutions for bedrooms and living rooms may be the most widely accepted products across these houses. Alternatively, skylights and windows with limited outside views are anticipated to be most suitable for secondary glazing solutions. Modular, removable products may be particularly suited towards tenants living privately rented accommodation, especially if landlords are unwilling to pay for energy efficiency measures themselves. Internal solutions aiming to improve the windows in homes limited by planning restrictions may only be suitable if incorporated adequately. Bathroom windows may not be suitable due to potential condensation risks.

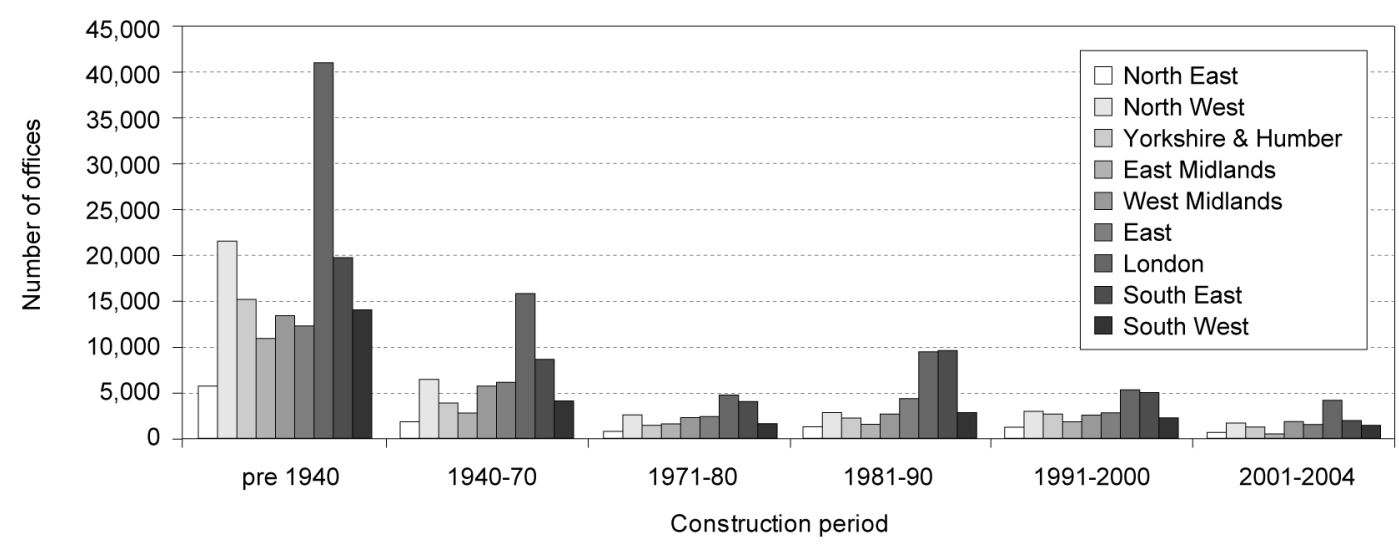

[Figure 16. English office stock segmented by construction period and location (Generated from CLG 2004)]

The commercial office stock may be another sector where translucent insulation solutions are equally or more appropriate. As shown in Figure 16, the majority of offices in England were constructed pre-1940, thus are very likely to have single glazed windows. Secondary glazing solutions aimed at this sector, could cover large areas of the façade where a clear view is not necessary. Alternatively, roller shutters, airtight blinds, or sliding screens could be particularly effective for insulating windows in winter, yet providing a clear view in summer. In order to be widely accepted across the sector, it is essential that suitable day-lighting levels be maintained. BMS controls could be integrated into openable products to optimise both the thermal and optical performance. Understandably, widespread applicability, will require solutions to have a lower capital cost to new glazing systems.

\subsection{Conclusion}

The results of this study prove Baker's (2008) hypothesis that an $80 \%$ reduction in heat loss through single glazing is achievable by designing a purpose built retrofit solution containing aerogel. Baker (2008) tested the performance of a wooden shutter lined with strips of Spacetherm ${ }^{\circledR}$ - an opaque fibrous insulation containing aerogel particles. This study shows that by utilising translucent aerogel granules, a lightweight product containing a consistent layer of insulation can be produced, which does not block out all of the useful natural light. Compared to previous research investigating the performance of granular aerogel systems, results provide the first indication of the materials thermal and optical performance when applied to low cost retrofit solutions seeking to retain existing windows. This knowledge is valuable, since it is anticipated to increase the widespread applicability for granular aerogel across both the domestic and commercial glazing market. Payback calculations indicate that granular aerogel is capable of providing cost effective energy savings within the product lifespan, even if an openable solution is introduced. Note that payback periods can be significantly increased if an openable solution is not operated consistently throughout the heating season. 
Future research will seek to (i) map out all ways granular aerogel can be applied to the existing UK building stock to reduce demand for heating and artificial lighting, (ii) investigate which solutions are most widely applicable, considering physical or planning constraints, and (iii) identify which systems offer the greatest potential for widespread $\mathrm{CO}_{2}$ savings over the lifecycle. A key issue to consider is how to design solutions that accommodate for occupant behaviour to ensure it can be installed and used in the most cost effective way. A thorough understanding of design conflicts is required to enable development to be targeted towards the most appropriate shapes, sizes and types of windows across different types of buildings. Aerogel is a unique material, with potential for many applications in new insulation products. Innovative materials such as this should not be overlooked in the effort to reduce $\mathrm{CO}_{2}$ emissions across our existing building stock.

\section{Acknowledgements}

The author would like to thank the EPSRC, Brunel University and Buro Happold Ltd for funding this research. Additional thanks go to the reviewers for their constructive comments.

\section{References}

Bahaj A, James P and Jentsch M, 2008. Potential of Emerging Glazing Technologies for Highly Glazed Buildings in Hot Arid Climates, Journal of Energy and Buildings, Volume 40, pp. $720-731$

Baker P, 2008. Improving the Thermal Performance of Traditional Windows [online], Glasgow Caledonian University, Historic Scotland, Centre for Research on Indoor Climate \& Health. Available from: http://www.historic-scotland.gov.uk/thermal-windows.pdf [Accessed 15 March 2009]

Beaumont A, 2007. Hard to Treat Homes in England, W07 - Housing Regeneration and Maintenance [online], International Conference 25th-28th June - Sustainable Urban Areas Rotterdam 2007, Housing Centre, Building Research Establishment, Watford, UK, Available from: http://www.enhr2007rotterdam.nl/documents/W07 paper_Beaumont.pdf [Accessed 16 March 2010]

British Standards Institution, 2007. BS EN ISO 6946:2007, Building components and building elements - Thermal resistance and thermal transmittance - Calculation method, BSI Group, London

Bynum R, 2001. Insulation Handbook, Chapter 12 - Radiant Barriers and Reflective Insulation, McGraw-Hill, New York, USA

C\&A Supplies Ltd, 2010. Polycarbonate Sheets [online], Available from: http://www.casupply.co.uk/acatalog/polycarbonate_sheeting.html [Accessed 20 Jan 2010]

Cabot Corporation, 2004. Cabot Nanogel Promises Unmatched Energy Savings Revolutionary Insulating Material makes the Best Window, Wall and Skylight Products Better, Journal of Pigment \& Resin Technology, Volume 33, Issue 6, pp 345

Cabot Corporation, 2009. Nanogel Translucent Aerogel [online], Available from: http://www.cabot-corp.com/wcm/download/en- 
us/ae/New $\% 20$ EURO $\% 20$ General $\% 20$ brochure $\% 20$ -

\%20Engl\%20073778\%20GOOD\%20FORMAT.pdf [Accessed 7 April 2009]

Cabot Corporation, 2010. Façade Systems with Nanogel ${ }^{\circledR}$ [online], Cabot Corporation \& Roda, Available from: http://www.cabot-corp.com/wcm/download/en-

us/ae/Facade\%20systems\%20roda.pdf

[Accessed 01 November 2010]

Campbell Scientific, 2005. CR23X specifications [online], Available from:

http://www.campbellsci.com/documents/product-brochures/s_cr23x.pdf [Accessed 18 May 2010]

Carbon Trust, 2008. CTG004 Technology Guide, Degree Days for Energy Management - A Practical Introduction, London

Cheeseman B, Mavroulidou M, Maidment G, Smith M and Potter N, 2007. Developing an Insitu Post Construction Quality Control Methodology to Ensure Better Energy Efficiency of Buildings, Proceedings of the 10th International Conference on Environmental Science and Technology, 5-7 September 2007, Kos Island, Greece

Chung D L, 2010. Composite Materials: Functional Materials for Modern Technologies, 2nd Edition, Springer, New York, USA

CIBSE, 2006. Environmental Design - CIBSE Guide A, 7th Edition, Chartered Institute of Building Services Engineers, London, CIBSE Publications Department

CIBSE, 2008. CIBSE TRY Hourly Weather Data Set - London [online], Test Reference Year from 1983-2004 data sets, Available from http://www.cibse.org/index.cfm?go=publications.view\&item=332 [Accessed 08 November 2010]

Climate Change Act, 2008. Carbon Targeting and Budgeting, Chapter 27, Part 1 - The Target for 2050, Her Majesty's Stationery Office Limited, UK

CLG 2004, Age of Commercial and Industrial Stock [online], Communities and Local Government, Available from http://www.communities.gov.uk/archived/publications/planningandbuilding/ageindustrialstock [Accessed 10 June 2009]

CLG, 2006. Summary Statistics - Insulation and Homes [online], Communities and Local Government, Available from: http://www.communities.gov.uk/documents/housing/xls/summarystats2006.xls [Accessed 10 June 2009]

CLG 2010. English Housing Survey, Household Report 2008-2009 [online], Communities and Local Government, Available from: http://www.communities.gov.uk/publications/corporate/statistics/ehs200809householdreport [Accessed 05 November 2010] 
Dolley P, Martin C and Watson M, 1994. Performance of Walls Clad with Transparent Insulation Material in Realistic Operation, Journal of Building and Environment, Volume 29, Issue 1, pp 83-88

Duer K and Svendsen S, 1998. Monolithic Silica Aerogel in Super insulating Glazings, Journal of Solar Energy, Volume 63, Issue 4, pp. 259-267

EEPH - Energy Efficient Partnership for Housing, 2008. The Insulation Industry, Working in Partnership with Government to Insulate the Existing Housing Stock by 2050 [online], Available from:

http://www.eeph.org.uk/uploads/documents/partnership/Insulation $\% 20 \mathrm{briefing} \% 20 \mathrm{paper} \% 20 \mathrm{Fi}$ nal\%20v3\%2007\%2008\%2008.pdf [Accessed 10 June 2010]

Fricke J and Tillotson T, 1997. Aerogels: Production, Characterization and Applications, Journal of Thin Solid Films, Volume 297, pp. 212-223

GGF 2009. Carbon calculator [online], Glass and Glazing Federation, Available from: http://www.ggf.org.uk/carbonCalculator.aspx [Accessed 10 June 2009]

Greenspec 2010, Insulation Materials Compared - Oil derived insulation [online], Available from: http://www.greenspec.co.uk/html/materials/insulation-oil_derived.html [Accessed 18 May 2010]

Haruyama, 2001. Performance of Peltier Elements as a Cryogenic Heat Flux Sensor at Temperatures Down to 60K, Journal of Cryogenics, Volume 41, pp335-339

HM Government, 2010. Conservation of Fuel and Power Approved Document L1B, The Building Regulations 2000, 2010 Edition, NBS, Riba Enterprises, London

HM Treasury, 2003. The Green Book: Appraisal and Evaluation in Central Government, Treasury Guidance, The Stationary Office, London

Hollands K, 1965. Honeycomb Devices in Flat-Plate Solar Collectors, Journal of Solar Energy, Volume 9, Issue 3, pp. 159-164

Hutchins M and Platzer W, 1996. The Thermal Performance of Advanced Glazing Materials, Journal of Renewable Energy, Volume 8, Issues 1-4, pp. 540-545

Jensen K, Schultz J and Kristiansen F, 2004. Development of Windows Based on Highly Insulating Aerogel Glazings, Journal of Non-Crystalline Solids, Volume 350, pp 351-357

Jones I and Rudlin J, 2006. Process Monitoring Methods in Laser Welding of Plastics, Proceedings of the 2nd International Conference on Joining Plastics, National Physical Laboratory, 25-26 April 2006, London, pp233

Kaushika N and Sumathy K, 2003. Solar transparent insulation materials: a review, Journal of Renewable and Sustainable Energy Reviews, Volume 7, pp. 317-351

Klems J and Keller H, 1988. In-Situ Measurements of Fenestration U-Values and Overall Thermal Performance, Windows and Daylighting Program, Applied Science Division, Lawrence Berkeley Laboratory, USA 
Lien A, Hestnes A and Aschehoug Ø, 1997. The use of Transparent Insulation in Low Energy Dwellings in Cold Climates, Journal of Solar Energy, Volume 59, Issues 1-3, pp. 27-35

Martin C and Watson M, 1990. A Field Test of the Performance of an Opaque wall clad with Transparent Insulation Material. Contractor Report, Department of Energy, Renewable Energy. EMC Report to ETSU S1197-P8.

Mitchell M, 2000. Design and Micro-Fabrication of a Molded Polycarbonate Continuous Flow Polymerase Chain Reaction Device, Thesis (PhD). Department of Mechanical Engineering, Louisiana State University, USA

MTP - Market Transformation Programme, 2007. Innovation BN - Innovative Glazing; Supporting UK Government Policy on Sustainable Products [online], Available from: https://www.pauljervis.net/filemgmt/visit.php?lid=197, [Accessed 14 July 2009]

Perspex, 2010. Perspex for Glazing: PXTD 236 [online], Available from: http://www.qdplastics.co.uk/assests/docs/acrylic/perspex_glazing236.pdf [Accessed 18 May 2010]

Peuportier B, Kohler N, Lewis O, Tombazis A and Voss K 2000. Education of Architects in Solar Energy and Environment [online], Altener Programme of the European Commission, DG TREN, Section 3.1 - Advanced glazing and transparent Insulation, Available from: http://www.cenerg.ensmp.fr/ease/advanced_glazing.pdf [Accessed 15 October 2010]

Platzer W, 1987. Solar transmission of transparent insulation material, Journal of Solar Energy Materials, Volume 16, Issues 1-3, pp. 275-287

Platzer W J and Goetzberger A, 2004. Recent Advances in Transparent Insulation Technology, Transparent Insulation - TI8, Fraunhofer-Institute for Solar Energy Systems, Freiburg, Germany

Power, A, 2008. Does Demolition or Refurbishment of Old and Inefficient Homes Help to Increase our Environmental, Social and Economic Viability? Journal of Energy Policy, Volume $36, \mathrm{pp} 4487$

Ravetz J, 2008. State of the Stock - What do we know about Existing Buildings and their Future Prospects? Journal of Energy Policy, Volume 36, pp4462-4470

RCEP - Royal Comission on Environmenatl Pollution, 2007. The Urban Environment Twenty-sixth report; pp.109, Norwich; The Stationery Office, UK

Reim M, Beck A, Körner W, Petricevic R, Glora M, Weth M, Schliermann T, Fricke J, Schmidt C and Pötter F, 2002. Highly Insulating Aerogel Glazing for Solar Energy Usage, Journal of Solar Energy, Volume 72, Issue 1, pp. 21-29

Reim M, Körner W, Manara J, Korder S, Arduini-Schuster M, Ebert H and Fricke J, 2005. Silica aerogel granulate material for thermal insulation and daylighting, Journal of Solar Energy, Volume 79, pp. 131-139 
Roberts S, 2008. Altering Existing Buildings in the UK, Journal of Energy Policy, Volume 36, pp4482-4486

Robinson P and Hutchins M, 1994. Advanced Glazing Technology for Low Energy Buildings in the UK, Journal of Renewable Energy, Volume 5, Issue 1, pp 298-309

Rubin M and Lampert C, 1983. Transparent Silica Aerogels for Window Insulation, Journal of Solar Energy Materials, Volume 7, pp 393-400

Schultz J, Jensen K and Kristiansen F, 2005. Super insulating aerogel glazing, Journal of Solar Energy Materials \& Solar Cells, Volume 89, pp. 275-285

Schultz J and Jenson K, 2008. Evacuated Aerogel Glazings, Journal of Vacuum, Volume 82, pp. 723-729

Schwertfeger F, Frank D and Schmidt M, 1998. Hydrophobic Waterglass Based Aerogels without Solvent Exchange or Supercritical Drying, Journal of Non-Crystalline Solids, Volume 225, pp24-29

Shorrock L, Henderson J and Utley J, 2005. Reducing Carbon Emissions from the UK Housing Stock, Watford, Watford, BRE Press

Utley J and Shorrock L, 2008. Domestic Energy Factfile 2008, Building Research Establishment, Watford, BRE Press

Vesma, 2009. UK Monthly and Weekly Degree Day Figures [online], Available from: http://www.vesma.com/ddd/index.html [Accessed 10 June 2009]

Wittwer V, 1992. Development of aerogel windows, Journal of Non-Crystalline Solids, Volume 145, pp. 233-236

Werner M and Brand L, 2010. Focus Report 2010 - Aerogels [online], General sector reports, chemistry and materials, ObservatoryNANO, p12

http://www.observatorynano.eu/project/filesystem/files/WP2_ChemistryMaterials_FocusRepor t_Aerogels_29_04_2010.pdf [Accessed 20 Jan 2011]

Wong L, Eames P and Perera R, 2007. A Review of Transparent Insulation Systems and the Evaluation of Payback Period for Building Applications, Journal of Solar Energy, Volume 81, pp1058-1071

Yokogawa H, 2005. Handbook of Sol-Gel Science \& Technology, Volume 2, Chapter 13 Thermal Conductivity of Silica Aerogels, Sumio Sakka (editor), Kluwer Academic Publishers, New York, USA

Zhu Q, Li Y and Qui Z, 2007. Research Progress on Aerogels as Transparent Insulation Materials, Challenges of Power Engineering and Environment, International Conference on Power Engineering, October 23rd-27th, Hangzhou, China, Volume 1, pp. 1117 - 1121

Zimmerman M and Bertschinger H, 2001. High Performance Thermal Insulation Systems: Vacuum Insulation Products (VIP), Proceedings of the International Conference and Workshop EMPA, 22-24 January 2001, International Energy Agency, Duebendorf, pp8 